\title{
KAEDAH PEMBUKTIAN \\ DALAM KES HUDUD
}

\author{
By: \\ Paizah Haji Ismail ${ }^{*}$
}

\begin{abstract}
There have been discussions among Islamic jurists whether the court is bound to certain guidelines in deciding the methods of evidence in criminal cases. The purpose of this article is to shine some light on this issue especially with connection to certain evidence, which is not accepted by some Islamic jurists. For the purpose, every single opinion has been analysed together with others in a method of comparative study. The analysis shown that although there are some differences in detail between the jurists, yet principally they agreed that the Islamic Syariah has imposed various conditions in matters related to Hudud cases for the sake of justice. For the purpose of contemporary fiqh the diference in opinion between jurists can be considered as a starting point towards a contemporary development in the subject mater.
\end{abstract}

\section{PENDAHULUAN}

Kaedah pembuktian bermaksud cara yang digunakan bagi membuktikan kesalahan dihadapan mahkamah. Sebagai suatu kaedah bagi tujuan khusus, ia mungkin berbeza daripada

* Prof. Madya, Jabatan Fiqh \& Usul, Akademi Pengajian Islam, Universiti Malaya, Kuala Lumpur. 
"pembuktian" dalam konsepnya yang umum. Kerana, dalam konsepnya yang umum, pembuktian tidak semestinya di hadapan mahkamah dan tidak terikat dengan cara-cara tertentu. Sedangkan dalam konsepnya yang khusus ini ia perlu dilakukan di hadapan mahkamah dan perlu menggunakan cara-cara yang tertentu.

Ini bererti, kadangkala sesuatu "kebenaran" pada pandangan mahkamah tidak sama dengan realiti sebenar di luar mahkamah. Dengan kata lain, kadangkala apa yang diputuskan oleh mahkamah bertentangan dengan realiti sebenar di luar mahkamah. Semuanya terhenti atas samada realiti yang sebenar di luar mahkamah itu berjaya dibuktikan dengan cara-cara tertentu yang ditetapkan oleh undang-undang yang terpakai bagi mahkamah berkenaan.

Sehubungan dengan ini mahkamah sebenarnya berhadapan dengan dua nilai. Pertamanya, nilai keadilan. Berasaskan kepada nilai ini apa juga cara perlu digunakan asalkan keadilan itu dapat ditegakkan sementara nilai kedua pula ialah kemantapan atau kestabilan urusan guaman yang dilakukan. Berasaskan kepada nilai ini hakim perlu terikat dengan cara-cara tertentu dan bagaimana dia menilai hujah-hujah yang dikemukakan agar dia lebih telus dan terdapat keselarasan yang jelas di kalangan para hakim dalam menentukan hukuman.

Di bawah sistem kehakiman konvensional, terdapat berbagai pandangan dalam usaha mencari penyelesaian di antara dua nilai ini. ${ }^{1}$ Ada yang berpendapat mahkamah perlu bebas dalam mencari kebenaran dan tidak patut terikat dengan kaedah pembuktian tertentu. Ada pula yang berpendapat sebaliknya, iaitu mahkamah perlu terikat dengan kaedah tertentu yang digariskan oleh undang-undang berkenaan. Selain itu ada pula pendapat yang membezakan antara kes-kes jenayah dan kes-kes sivil. Berasaskan kepada pandangan ini, dalam kes-kes jenayah mahkamah perlu bebas sepertimana yang dicadangkan oleh pandangan pertama tadi sementara dalam kes-kes sivil mahkamah perlu terikat dengan kaedah-kaedah tertentu sebagaimana yang disarankan oleh pandangan kedua.

Aḥmad Mu'āfī (1965), Min al-Fiqh al-Jinā'ì al-Muqārin Bayna alSharì 'ah al-Islāmiyyah wa al-Qānūn. Kaherah: Dār Wa Matabi ‘ alSya 'b, h. 272. 


\section{PANDANGAN SYARIAH ISLAM}

Dr. Aḥmad Mu'āfī dalam buku beliau Min al-Fiqh al-Jinā'i Bayna al-Syari' 'ah al-Islāmiyah wa al-Qānūn ${ }^{2}$ menyebut, Syariah Islam lebih cenderung kepada mengikat mahkamah dengan kaedah pembuktian tertentu dalam kes-kes jenayah. Walau bagaimanapun, terdapat pandangan yang sebaliknya iaitu yang diutarakan oleh Ibn al-Qayyim dalam bukunya I'làm al-Muwaqqi 'in dan al-Turuq al-Hukmiyyah.

Dalam I'làm al-Muwaqqi 'ín ${ }^{3}$ Ibn al-Qayyim menyebut:

"Dalam semua persoalan, Syariah Islam bertujuan untuk menjelaskan kebenaran walau dengan apa cara sekalipun, dan tidak akan menolak apa-apa sekalipun, dan tidak akan menolak apa-apa kebenaran apabila ada dalil yang jelas mengenainya. Kerana dengan penolakan seperti itu hak-hak Allah atau hambanya akan hilang atau terganggu. Sebenarnya kelahiran kebenaran itu tidak hanya bergantung kepada perkara tertentu sahaja. Oleh kerana itu tidak perlu ditentukan kaedah tertentu dalam menjelaskan kebenaran sedangkan kaedah lain juga boleh memainkan peranan yang sama tanpa apa-apa perbezaan."

Dalam al-Ṭuruq al-Hukmiyyah ${ }^{4}$ pula beliau menegaskan:

"Apabila tanda-tanda keadilan itu telah jelas, baik dengan apa cara sekalipun maka itulah Syariat dan agama Allah. Kerana Allah SWT lebih mengetahui, lebih bijaksana dan lebih adil dari hanya menentukan kaedah tertentu dalam memperjelaskan keadilan dan tanda-tandanya sedangkan ada cara-cara lain lagi yang lebih berkesan dan lebih telus. Malah Allah telah memperjelaskan bahawa apa yang penting ialah menegakkan keadilan itu sendiri di antara para hambanya dan supaya manusia berlaku adil. Maka apa sahaja cara yang boleh menegakkan keadilan dan kesaksamaan ia adalah kehendak agama dan tidak bertentangan dengannya."

\section{Ibid., h. 272.}

3 Ibn Qayyim al-Jauziyyah (1970), I'lām al-Muwaqqi 'ìn. Kaherah: alNahḍah al-Jadidah, h. 9

4 Ibn Qayyim al-Jauziyyah (1318H), al-Ṭuruq al-Hukmiyyah Fī alSiyāsah al-Syar'iyyah. Kaherah: Maṭba 'ah al-Ādāb, h. 22. 
Tertarik dengan pandangan Ibn al-Qayyim ini, Dr. Aḥmad Fathī Bahnasi ${ }^{5}$ berpendapat dalam Syariat Islam mahkamah tidak terikat dengan apa-apa kaedah tertentu dalam membuktikan kesalahan. Sebaliknya ia mempunyai kebebasan untuk menerima apa sahaja keterangan yang boleh memperjelaskan kebenaran.

Bagi memperjelaskan lagi prinsip terbuka berkenaan Dr. Bahansi menukilkan penegasan-penegasan Ibn al-Qayyim selanjutnya sepertimana berikut:

"Syariat Islam tidak hanya membataskan kepada kesaksian dua orang lelaki dalam menentukan kebenaran samada dalam kes-kes penumpahan darah, harta, perzinaan ataupun dalam kes-kes hudud. Malah para Khalifah al-Rasyidun dan para sahabat Rasulullah yang lain pernah menjatuhkan hukuman dalam kes zina berasaskan mengandung dan dalam kes minum arak berasaskan bau dan muntah."

Begitulah juga apabila didapati barang curi pada seseorang, orang tersebut lebih perlu dihukum dengan hukuman hudud daripada orang yang mengandung (tanpa suami) dan orang yang ada bau arak (di mulutnya). Segala bentuk gejala bau arak ada pada gejala terdapatnya barang curi pada seseorang, malah dengan cara yang lebih tegas. Ini kerana keraguan yang terdapat pada gejala mengandung, misalnya disebabkan oleh persetubuhan secara paksa atau secara "syubhah", begitu juga yang ada pada gejala bau mulut dalam kes minum arak tidak ada dalam kes penemuan barang curi pada seseorang.

Para Khalifah al-Rasyidun dan para sahabat Rasulullah SAW sebenarnya tidak mengambil kira dengan keraguan seperti ini. Kerana pengambilkiraan keraguan seperti ini boleh membuka jalan ke arah penolakan kesaksian para saksi atas alasan yang sama. Kerana keraguan dalam kesaksian sebenarnya lebih besar daripada keraguan yang ada dalam keterangan-keterangan di atas tadi. Maksudnya, kalau keterangan-keterangan seperti tadi ditolak maka keterangan saksi lebih utama ditolak." ${ }^{\prime 6}$

5 Aḥmad Fatḥi Bahnasī (1962), Nazariyat al-Ithbāt Fì al-Fiqh alJina'ì al-Islāmì. Kaherah: al-Syarikah al- 'Arabiyah Li al-Ṭībā'ah Wa al-Nasyr, h. 10.

6 Ibn al-Qayyim (1970), op.cit., j. 1, hh. 103-104. 
Maka berasaskan prinsip yang terbuka ini Dr. Aḥmad Fathī Bahansi berpendapat ada tujuh cara yang boleh digunakan dalam membuktikan kes jenayah, iaitu kesaksian, pengakuan, bahan bukti (qarinah), keterangan pakar (al-khibrah), pengetahuan hakim, dokumen (al-kitābah) dan sumpah. Semuanya ini boleh disebut dalam satu istilah yang sama, iaitu keterangan (al-bayyinah). ${ }^{7}$

Bagaimanapun, dalam penulisan ini tumpuan akan diberikan kepada keterangan-keterangan yang boleh diterima dalam kes-kes hudud sahaja memandangkan persoalan yang dibincangkan di sini khusus tentang jenayah hudud, iaitu:

\section{Keterangan Saksi (al-Syahādah)}

Dalam al-Quran Allah berfirman:

Maksudnya:

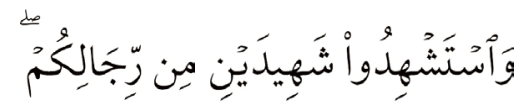

"Maka hendaklah kamu bersaksikan dua saksi lelaki dari kalangan kamu”

Surah al-Baqarah (2) : 282

Firman Allah lagi:

Maksudnya:

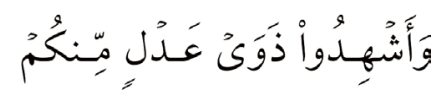

"Maka hendaklah kamu melantik saksi dari kalangan yang adil di antara kamu"

Surah al-Ṭalāq $(65): 2$

Dalam hadis, antara lain Rasulullah SAW pernah bersabda kepada pihak pendakwa:

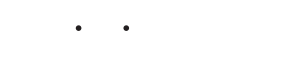

Maksudnya:

"Dua saksi kamu atau sumpahnya (yang terdakwa)"

(Riwayat Bukhārī)

7 Aḥmad Fathịi Bahnasī (1962), op.cit., h. 12. 
Selain di atas terdapat berbagai-bagai ayat dan hadis yang memberi pengertian yang sama, iaitu menunjukkan bahawa keterangan saksi merupakan suatu asas yang perlu diterima dalam menentukan keputusan di mahkamah. Dengan kata lain, ia mengikut hakim dalam membuat keputusan apabila segala syarat yang diperlukan dipenuhi.

Berasaskan kedudukan ini, seseorang yang layak memberi keterangan sebagai saksi berkewajipan memberi keterangan yang diperlukan oleh mahkamah. Dalam kes-kes sivil atau dalam istilah yang lebih tepat, kes-kes yang melibatkan hak individu kewajipan itu berlaku apabila dia diminta memberi keterangan berkenaan. Sementara dalam kes-kes yang melibatkan hak awam (Haqqullah) pula kewajipan berlaku walaupun tanpa diminta. Ini kerana ia merupakan hak yang boleh dituntut oleh pendakwa. ${ }^{8}$

Bagaimanapun, dalam kes-kes hudud secara khusus, seseorang boleh memilih samada mahu memberi keterangan berkenaan secara sukarela (Hisbah) atau sebaliknya dengan tujuan untuk melindungi maruah pihak yang melakukan kesalahan berkenaan. Malah terdapat hadis-hadis Rasulullah SAW yang memberi erti bahawa langkah melindungi maruah dengan cara tidak memberi keterangan seperti itu lebih diutamakan (afdal).

Dalam sebuah hadis Rasulullah SAW bersabda9:

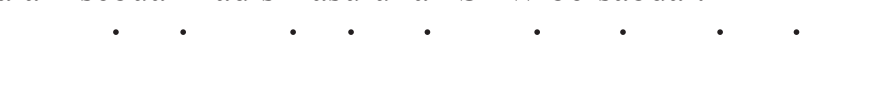

Maksudnya:

"Sesiapa yang melindungi (maruah) seseorang muslim Allah akan melindungi di dunia dan di akhirat"

(Riwayat Ibn Mājah)

Dalam suatu hadis yang lain baginda Rasululah SAW bersabda kepada seorang yang bernama Huzāl al-Aslāmì apabila orang

8 Ibn al-Humām (1315H), Fath al-Qadìr, j. 6. Kaherah: Mațba 'ah alAmiriyah, h. 2; Manlakhasur (1319H), Durur al-Hukkām Fì Syarh Gharar al-Ahkām, j. 2. Kaherah: Mațba 'ah al-Amiriyah, h. 371.

9 Ibn Mājah (t.t.), Sunan Ibn Mājah. Mekah: al-Maktabah al-Tijāriyah, h. 850 . 
tersebut membuat keterangan kesaksian di hadapan baginda. Sabda Rasulullah SAW:

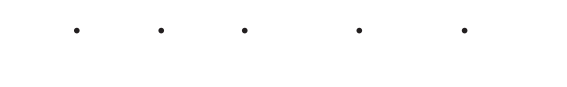

Maksudnya:

"Kalau kamu lindunginya dengan pakaian kamu tentu sekali lebih baik bagi kamu."

(Riwayat Abu Daud)

Perbezaan antara kes hudud dan kes-kes lain ini mempunyai asas yang jelas. Dalam kes-kes yang melibatkan hak individu, ada hak yang akan luput kalau sekiranya orang yang sepatutnya menjadikan saksi enggan memberi keterangan. Sebaliknya dalam kes hudud kehilangan hak seperti itu tidak akan berlaku, maka perlindungan terhadap maruah tertuduh wajar diutamakan

Kes mengambil harta orang telah dijadikan contoh yang praktikal oleh sesetengah fuqaha bagi menghuraikan perkara ini. Kalau sekiranya orang yang sepatutnya menjadi saksi dalam kes berkenaan tidak bersedia langsung untuk memberi keterangan, hak tuan punya harta untuk mendapatkan kembali hartanya yang diambil orang itu luput begitu sahaja. Tetapi kalau sekiranya saksi berkenaan memberi keterangan berasaskan jenayah mencuri, dia tidak bersikap melindungi maruah saudaranya yang dituduh dalam kes itu. Maka sebaik-baiknya dia memberi keterangan untuk menegakkan kes sivil sahaja, iaitu mengambil harta orang secara tidak sah ${ }^{10}$ yang tidak melibatkan tertuduh yang tidak segan silu melakukan kejahatan berkenaan. Kerana mereka yang seperti itu tidak perlu dilindungi maruahnya dan perlu dihapuskan. ${ }^{11}$

Bagaimanapun, untuk layak menjadi saksi seseorang itu perlu memenuhi syarat tertentu. Bagi para fuqaha ${ }^{12}$ syarat-syarat tersebut dikategorikan kepada dua. Pertamanya kelayakan mempunyai maklumat (أهليّة الوجوب) dan keduanya kelayakan memberi keterangan tentang maklumat berkenaan (أهليّة الوحليّة الأداء).

\footnotetext{
10 Ibn al-Hummām (1315H), op.cit., j. 6, h. 3.

11 Ibid., j. 6, h. 114.

12 Aḥmad Fathị Bahnasī (1962), op.cit., h. 21.
} 
Untuk menjadi layak mempunyai atau memiliki maklumat berkenaan seseorang itu perlu waras, iaitu seorang dewasa yang tidak gila. Dengan kata lain, kanak-kanak dan orang gila tidak layak mempunyai maklumat berkenaan.

Untuk layak memberi keterangan pula, seseorang itu perlu seorang yang waras (رشيد), baligh, adil, maksudnya seorang yang tidak terkenal sebagai jahat, beragama, iaitu tidak pernah melakukan dosa besar atau sentiasa melakukan dosa kecil, bermaruah iaitu tidak berkelakuan tidak sopan dan sebagainya. ${ }^{13}$

Selain itu dia perlu benar-benar tahu tentang kes berkenaan dan semestinya lelaki serta tidak dipaksa memberi keterangan berkenaan. ${ }^{14}$

Dalam memberi keterangan, saksi tidak boleh menggunakan kecuali maklumat yang diabenar-benar tahu. Para fuqaha menyebut pengetahuan seperti itu dapat diperolehi melalui dua cara, iaitu melihat sendiri atau mendengar sendiri apa yang berlaku. ${ }^{15}$

Adalah menjadi tanggungjawab hakim untuk menyoal saksi berkenaan kalau sekiranya dalam keterangan yang diberikan itu terdapat keraguan atau hal yang tidak jelas. Dalam kes mencuri misalnya hakim perlu mempastikan bagaimana perbuatan itu berlaku bagi mengelak kemungkinan apa yang dilakukan oleh yang tertuduh itu bukan perbuatan mencuri yang boleh dikenakan hukuman hudud. Begitu juga tentang bila kejadian itu berlaku, untuk mempastikan bahawa pendakwaan telah dibuat dalam tempoh yang belum luput, dan sebagainya. ${ }^{16}$

13 Lihat huraian lanjut dalam Shams al-Dīn Muhammad 'Arfah alDusūqi (t.t.), Hạasyiah al-Dusūqì 'alā al-Sharh al-Kabīr, j. 4. Kaherah: al-Ḥalabi, h. 146; Ibn Qudāmah (t.t.), al-Mughnī, j. 14. Riyaḍ: Dār 'Alam al-Kutub, h. 42.

14 Al-Kasāni (t.t.), Bada'í 'al-Sanā'i, j. 6. Kaherah: Maṭba 'ah al-Imām, h. 272; Ibn al-Humam (1315H), op.cit., j. 6, h. 6; al-Dusūqi (t.t.), op.cit., j. 4, h. 146.

15 Ibn Qudāmah (t.t.), op.cit., j. 12, h. 19; Ibn al-Humām (1315H), ibid., j. 6, h. 55.

16 Ibn al-Humām (1315H), ibid., j. 4, h. 225. 
Khusus dalam kes zina, para saksi perlu disoal secara berasingan untuk mempastikan setiap mereka bercakap benar dengan menegaskan masing-masing melihat sendiri dengan jelas perbuatan berkenaan. Selain daripada kes zina, hakim boleh menyoal para saksi itu secara berasingan atau sebaliknya. ${ }^{17}$

Dari segi bilangan saksi, tidak semua kes memerlukan bilangan yang sama. Dalam kes zina, bilangan saksi yang diperlukan ialah empat. Syaratnya mereka mestilah melihat kejadian itu pada waktu yang sama dan sama-sama datang pada waktu yang sama untuk memberi keterangan. Bilangan yang sama juga diperlukan pada pandangan sesetengah para fuqaha dalam kes-kes liwat. Kerana bagi mereka perbuatan meliwat juga merupakan zina. Sementara pada pandangan sebahagian para fuqaha lain hanya perlu dua sahaja. Perbezaan pendapat ini berlaku juga dalam kes-kes lesbian dan menyetubuhi binatang. ${ }^{18}$

Dalam kes-kes selain hudud, bilangan yang diperlukan dua sahaja. Bagaimanapun dalam kes qadhf perlu ada perbezaan antara dua hal. Pertamanya untuk mensabitkan bahawa perbuatan qadhf itu sendiri benar-benar berlaku. Dalam hal ini dua orang saksi sudah memadai. Hal kedua ialah untuk mensabitkan bahawa yang kena qadhf itu seorang penzina. Bagi tujuan ini empat orang saksi diperlukan. ${ }^{19}$

\section{Pengakuan (al-Iqrar)}

Dalam al-Quran Allah berfirman:

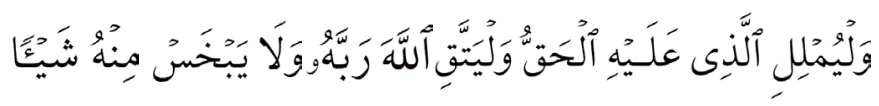

17 Al-Dirdir (1320H), al-Syarh al-Kabīr, j. 4. Kaherah: al-Ḥalabì, h. 164.

18 Manla Khasru (1319H), op.cit., j. 2, h. 377; Ibn Qudāmah (t.t.), op.cit., j. 12, h. 6; al-Dusūqi (ț.t), op.cit., j. 4, h. 283.

19 Ibn Qudāmah(t.t.), ibid., j. 10, h. 99; Ibn Rusyd (1389H), Bidāyat alMujtahid, j. 2. Kaherah: Maṭba'ah al-Kulliyah al-Azhariyah, h. 370. 
Maksudnya:

"Dan hendaklah orang yang berhutang itu mengimlakkan (apa yang akan ditulis itu) dan hendaklah dia bertaqwa kepada Allah Tuhannya dan janganlah dia mengurangi sedikitpun daripada hutangnya"

Surah al-Baqarah (2): 282

Dalam suatu ayat yang lain pula Allah berfirman:

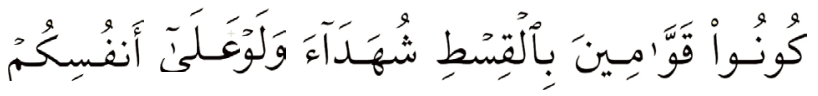

Maksudnya:

"Jadilah kamu orang yang benar-benar penegak keadilan menjadi saksi kerana Allah biarpun terhadap dirimu sendiri."

Surah al-Nisa' (4): 135

Dalam hadis Rasulullah SAW, pengakuan Ma iz telah diterima oleh Baginda Rasulullah SAW sebagai asas kepada sabitan jenayah zina ke atas lelaki itu yang kemudiannya direjam. ${ }^{20}$ Sementara dalam hadis al- 'Asaif pula Rasulullah SAW bersabda:

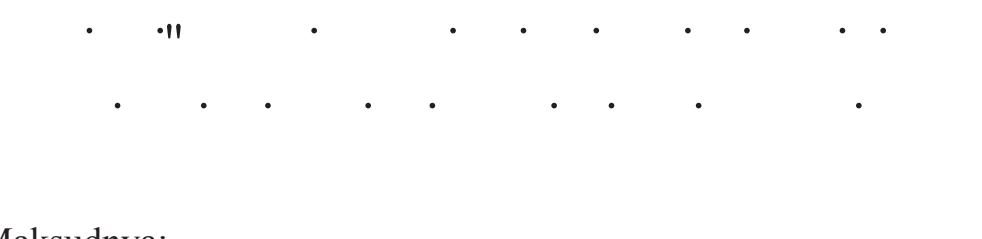

Maksudnya:

"Pergilah wahai Unais - seorang lelaki dari Aslam kepada isteri orang ini (yang menuduh isterinya berzina). Kalau dia mengaku rejamlah dia. Unais lalu pergi menemui perempuan itu. Perempuan itu telah mengaku, laku Rasulullah SAW memerintahkan supaya direjam dan dia lalu direjam. "'21

(Riwayat Muslim)

20 Hadis Muttafaq 'Alaih. Untuk huraian sepenuhnya lihat Muhammad bin Āli bin Muḥammad al-Syawkāni (1973), Nayl al-Awtār, j. 7. Beirut: Dār al-Jayl, hh. 259-261.

21 Muslim (2000), Saḥịh Muslim. Beirut: Dār İhya ‘ al-Turāṭh al- ‘Arabī, h.763 
Semuanya ini menunjukkan bahawa pengakuan (Iqrar) diterima sebagai asas dalam mensabitkan kes, termasuk dalam kes-kes hudud. Bagaimanapun, untuk diterima oleh mahkamah ia perlu memenuhi syarat-syarat tertentu.

Antara syaratnya ialah orang yang membuat pengakuan melakukan jenayah itu mestilah seorang yang waras dan cukup umur. Berasaskan syarat ini pengakuan kanak-kanak di bawah umur, orang gila dan orang bodoh (al-ma 'tuh) tidak sah, iaitu tidak boleh diterima oleh mahkamah. ${ }^{22}$

Selain daripada itu, mestilah pengakuan berkenaan dalam bentuk kata-kata, bukan dalam bentuk tulisan atau isyarat. Bagaimanapun, para fuqaha tidak sependapat tentang pengakuan orang bisu melalui isyarat yang boleh difahami. Bagi mazhab Syāfi $\bar{i}$ ia boleh diterima tetapi bagi mazhab Hanafí ia sebaliknya. ${ }^{23}$

Satu syarat lain ialah bahawa pengakuan itu sendiri munasabah, iaitu selaras dengan kebiasaan hidupyang ada. Misalnya, pengakuan berzina oleh seorang yang tidak mempunyai alat kelamin tidak boleh diterima kerana amat jelas sekali dia berbohong. ${ }^{24}$

Adalah menjadi kewajipan ke atas hakim untuk menyoal orang yang membuat pengakuan itu untuk mengetahui samada dia memahami apa yang dikatakan olehnya itu, mempunyai objektif yang jelas, juga memahami implikasinya, termasuk yang berkait dengan hukuman. Malah, khusus dalam kes-kes hudud hakim di sunatkan memandu orang yang membuat pengakuan itu supaya menarik balik pengakuan tersebut kerana tiada siapa yang akan menanggung kerugian dengan penarikan balik pengakuan seperti itu. Ini mermandangkan bahawa hudud menyentuh hak Allah (masyarakat) dan tidak menyentuh apa-apa hak individu. ${ }^{25}$

22 Muḥammad bin Aḥmad bin Abī Sahal Al-Sarakhsi (1957), al-Mabsūt, j. 9. Kaherah: Mațba 'ah al-Sa'ādah, h. 184; Abỉ Ishāa Ibrāhīm bin 'Alì bin Yūsuf al-Syirāzi (t.t.), al-Muhadhdhab, j. 2. Kaherah: alHalābi, h. 344.

23 Ibn Qudāmah (t.t.), op.cit., j. 10, h. 171; al-Kāsāni (t.t.), op.cit., j. 7, h. 51 .

24 Al-Sarakhsi (1957), op.cit., j. 9. h. 98.

25 Manla Khasru (1319H), op.cit., j. 2, h. 62; al-Kāsāni (t.t.), op.cit., j. 7, h. 51. 
Walau bagaimanapun, pengakuan hanya akan melibatkan pihak yang membuat pengakuan itu sahaja dan tidak sekali-kali akan melibatkan pihak ketiga. Kalau sekiranya seorang lelaki membuat pengakuan berzina dengan seorang perempuan tertentu kesalahan tersebut hanya akan sabit ke atas dirinya sahaja dan tidak atas perempuan itu, kecuali kalau perempuan itu juga mengaku. ${ }^{26}$

Mengikut pendapat yang rajih, untuk diterima oleh mahkamah sebagai asas menentukan hukuman, pengakuan sepertimana yang dibincangkan di atas perlu dilakukan dalam kontek pendakwaan yang ada. Misalnya dalam kes mencuri semata-mata mengaku mencuri tanpa didahului oleh adanya aduan atau dakwaan oleh pihak yang menjadi mangsa pencurian tersebut, pengakuan itu tidak boleh diterima. Bagaimanapun, sesetengah para fuqaha tidak berpendapat pendakwaan merupakan syarat perlu bagi penerimaan pengakuan. ${ }^{27}$

Satu syarat lain bagi penerimaan pengakuan sebagai asas penentuan hukuman ialah bahawa pengakuan itu mestilah dilakukan dengan pilihan sendiri dan tidak dipaksa. Dengan kata lain yang lebih tepat ia tidak dipengaruhi oleh sesuatu yang mencacatkan kebebasan memilih seperti paksaan, mabuk, gila dan sebagainya. ${ }^{28}$

Dari segi bilangan kali pengakuan itu sendiri supaya boleh diterima sebagai asas hukuman oleh mahkamah terdapat keperluan berbeza di antara satu jenayah dengan jenayah yang lain. Dalam kes zina misalnya yang diperlukan ialah sebanyak empat kali. Ini berasaskan kepada hadis Rasulullah SAW dalam kes Mā'iz, dimana sesudah pengakuan itu berlaku sebanyak empat kali barulah Rasulullah SAW menerimanya. Walau bagaimanapun, ada juga para ulama yang tidak melihat kekerapan itu sebagai syarat penerimaan. Mereka berhujah dengan hadis al-'Asaif dan

26 Al-Kāsāni (t.t.), ibid., j. 4, h. 120; Ibn Qudāmah (t.t.), op.cit., j. 10, h. 168; al-Sarakhsī (1957), op.cit., j. 18, h. 125.

27 Manla Khasru (1319H), op.cit., j. 2, h. 83.

28 Ibn al-Hummām (t.t.), op.cit., j. 4, h. 188. 
al-Ghamidiyah. Dalam hadis-hadis tersebut tiada sebutan tentang bilangan pengakuan yang dimaksudkan. ${ }^{29}$

Dalam kes-kes mencuri dan meminum arak sesetengah para fuqaha mensyaratkan dua kali pengakuan. Bagaimanapun, pandangan terbanyak mengatakan dalam kes-kes seperti ini soal bilangan tidak berbangkit. Perbezaan pendapat seperti ini berlaku juga dalam kes qadhf. Ia berpunca daripada tanggapan yang berbeza-beza tentang hadis-hadis Rasulullah SAW dalam kes-kes seperti itu.

Tentang cara melakukan pengakuan pula, para fuqaha berbeza pendapat samada hakim wajar bertanya tentang bilakah kesalahan yang diakui itu berlaku. Kalangan yang mengatakan tidak wajar memberi alasan kerana soalan itu tidak perlu. Ini kerana keperluan soalan seperti itu ketika saksi memberi keterangan ialah untuk menentukan bahawa keterangan saksi itu berlaku dalam tempoh masa yang dibenarkan, iaitu sebelum luput jangka waktu tertentu (al-Taqadum). Sedangkan pengakuan tidak terikat dengan tempoh luput.

Bagi mereka yang berpendapat wajar pula, soalan seperti itu memang ada faedahnya, iaitu untuk mempastikan bahawa jenayah yang diakui itu berlaku dalam tempoh pengaku berkenaan layak memikul tanggung jenayah, misalnya sesudah dia cukup umur. ${ }^{30}$

Selain tentang bila, hakim juga perlu bertanya tentang bagaimana. Ini untuk mempastikan bahawa orang yang membuat pengakuan itu benar-benar faham maksud jenayah yang diakui oleh beliau melakukannya itu. Dalam kes perzinaan, misalnya soalan yang perlu dikemukakan ialah tentang apa itu yang dimaksudkan dengan "zina" itu sendiri, bagaimana dia melakukan dan dengan siapa dia dilakukan. Malah keadaan beliau semasa melakukannya, samada dalam keadaan sebagai seorang muhsan atau sebaliknya. ${ }^{31}$

29 Ibn al-Athīr(1356H), Jāmi ‘ al-Ușūl fi Ahạāith al-Rasūl, j. 4. Kaherah: Maṭba 'ah al-Husainiyah, h. 277.

30 Manla Khasru (1319H), op.cit., j. 2, h. 62; al-Kāsāni (t.t.), op.cit., j. 7, h. 51.

31 Al- Kāsāni (t.t.), op.cit., j. 7, h. 52. 
Dalam hadis $\mathrm{Mu}$ 'adh, soalan seperti ini jelas sekali ditanyakan oleh Rasulullah SAW apabila lelaki itu berulang kali membuat pengakuan berzina di hadapan baginda Rasulullah SAW.

Malah sebahagian besar para fuqaha berpendapat boleh bagi hakim mendorong orang yang membuat pengakuan itu supaya menarik balik pengakuannya. Ada riwayat yang mengatakan Khalifah 'Umar Ibn al-Khațtāb apabila berhadapan dengan seorang yang di bawa menemuinya atas tuduhan mencuri terus bertanya orang itu" Awak mencuri? Katakan tidak" Kata orang itu "Tidak". Beliau lalu membiarkan orang itu pergi. Khalifah Abū Bakr, Abū Hurairah, Ibn Mas 'ūd dan Abū al-Dardā' juga diriwayatkan sebagai mempunyai pandangan yang sama. Sayidina 'Ali pula diriwayatkan telah mengherdik seorang yang telah membuat pengakuan mencuri di hadapannya dan menghalau orang itu dari sisinya. ${ }^{32}$

Dalam kes di mana pengakuan itu dibuat di luar mahkamah, dan kemudian pihak yang membuat pengakuan itu menafikan pengakuan berkenaan, pengakuan itu boleh disabitkan melalui kaedah pensabitan biasa, seperti melalui saksi dan sebagainya. Sehubungan dengan ini para fuqaha berbeza pendapat kalau hal seperti ini melibat kes perzinaan. Bagi sesetengah para fuqaha ia boleh disabitkan melalui dua orang saksi. Kerana itulah keperluan biasa dalam penerimaan keterangan saksi. Bagaimanapun, bagi golongan satu lagi, empat saksi diperlukan, kerana bilangan sebanyak itu diperlukan bagi mensabitkan kes zina melalui keterangan ${ }^{33}$ saksi.

Bagaimanapun, pengakuan yang dibuat di mahkamah itu sendiri boleh ditarik balik setakat yang menyentuh hak Allah (awam) semata-mata. Contohnya dalam kes zina dan minum arak. Bagaimanapun, kalau kes berkenaan menyentuh hak individu, seperti qadzaf dan mencuri ia tidak boleh ditarik balik.

32 Lihat Ibn al-Athīi (1356H), op.cit., j. 4, h. 285; Ibn Qudāmah (t.t.), op.cit., j. 10, h. 168. .

33 Ibn Qudāmah (t.t.), ibid., j. 10, h. 294; Manla Khasru (1319H), op.cit., j. 2, h. 74. 
Pada pandangan para fuqaha ada beberapa tindakan yang dianggap sebagai menarik balik pengakuan yang telah dibuat iaitu: ${ }^{34}$

1. Menyebut sendiri penarikan balik itu sebelum atau ketika hukuman berkenaan sedang dijalankan.

2. Cabut lari sewaktu hukuman sedang dijalankan. Walau bagaimanapun kalau perbuatan melarikan diri itu dilakukan sebelum hukuman itu dilaksanakan dia perlu ditangkap semula kecuali dia dengan jelas menyatakan menarik balik pengakuannya itu.

3. Berlaku percanggahan dalam pengakuan-pengakuan yang dilakukan oleh beliau. Dalam keadaan seperti ini penarikan balik pengakuan dikira telah berlaku.

\section{Bukti Keadaan (al-Qarīnah)}

Dalam bahasa Arab, istilah yang digunakan ialah Qiranah. Dari segi bahasa ia memberi erti perkaitan yang rapat dan berterusan.

Kedudukannya sebagai bukti terhadap sesuatu jenayah sentiasa tidak sama. Kerana ia berkait rapat dengan sekuat mana ianya berkait dengan jenayah itu sendiri. Kadangkala ia memberi suatu petunjuk yang amat meyakinkan sekali, dan kadang-kadang ia hanya memberi petunjuk yang bersifat kemungkinan kecil sahaja. Bagaimanapun, semuanya ini banyak dipengaruhi oleh kebijaksanaan seseorang membuat penilaian terhadapnya.

Di kalangan para fuqaha Islam, tokoh yang paling memberi perhatian kepada kedudukan "bukti" (Qarinah) ini sebagai satu jenis keterangan yang boleh digunakan di mahkamah ialah Ibn alQayyim al-Jauziyah. Dalam buku beliau al-Turuq al-Hukmiyyah Fì al-Siyāsah al-Syar'iyyah beliau menghuraikan dengan panjang lebar bagaimana jenis keterangan seperti ini perlu diterima oleh mahkamah termasuk dalam kes-kes hudud.

Kata beliau, apa yang dimaksudkan dengan keterangan (albayyinah) ialah apa saja yang boleh menjelaskan kebenaran. Ia

34 Manla Khasru (1319H), ibid., j. 2, h. 258; al-Sarakhsī (1957), op.cit., j. 9, h. 191; al- Kāsānì (t.t.), op.cit., j. 7, h. 232; Ibn al-Hummām (1315H), op.cit., j. 4, h. 199. 
tidak semestinya dalam bentuk saksi samada satu dua atau empat. Malah dalam al-Quran sendiri tidak pernah istilah "al-Baiyinah" itu digunakan bagi pengertian saksi.

Malah, kata beliau lagi, hadis Rasulullah SAW yang menyebut البيّنة علي المدّعي bermaksud supaya pihak pendakwa mengemukakkan hujah untuk membuktikan kebenaran dakwaannya itu. Meskipun antara hujah atau alasan yang dimaksudkan ialah keterangan saksi, tetapi ini tidak menolak penerimaan terhadap keterangan-keterangan dari jenis lain juga. Malah ada kemungkinan keterangan-keterangan jenis lain, terutama keterangan yang bersifat bukti kejadian (qarinat al-ḥăl) lebih meyakinkan daripada keterangan saksi. ${ }^{35}$

Bagaimanapun, para fuqaha berbeza pendapat tentang masalah penerimaan "bukti" (qarinah) ini, terutama dalam kes-kes hudud. Persoalan yang timbul ialah sejauh mana asas penerimaannya dalam al-Quran dan al-Sunnah dan samada ia tidak bertentangan dengan prinsip "menolak hudud kerana ada syubhah" (Dar' alHudūd bi al-Syubhāt).

Dalam kes penzinaan, perbezaan pendapat begitu ketara sekali tentang masalah ini. Jumhur fuqaha iaitu yang terdiri daripada para fuqaha mazhab Hanafi, Syāfi 'í dan Hanbali menolak keterangan jenis ini secara total. Bagaimanapun, mazhab Māliki berpendapat ia pada asasnya boleh diterima kecuali ada bukti yang menunjukkan ianya tidak boleh diterima.

Dalam kitab-kitab fiqh terdapat perbincangan yang menarik tentang kes perempuan yang tidak bersuami hamil. Para fuqaha mazhab Māliki berpendapat kalau sekiranya wanita itu adalah wanita tempatan dan tidak ada bukti yang menunjukkan dia dipaksa melakukan hubungan seks dia boleh dihukum hudud berasaskan bukti tersebut. Asas yang mereka pegang ialah katakata Khalifah 'Umar r.a. "Hukuman rejam wajib (dilaksanakan) ke atas sesiapa sahaja yang berzina, samada lelaki atau perempuan kalau sekiranya dia muhsan apabila ada keterangan saksi (albaiyyinah) atau dia mengandung atas atau ada pengakuan". ${ }^{36}$

Dalam al-Muwațta’ al-Imām Mālik menyebut:

35 Ibn Qayyim (1318H), op.cit., h. 12.

36 Ibn al-Athī (1356H), op.cit., j. 4, h. 263. 
"Saya mendapat maklum bahawa (Khalifah) 'Uthmān Ibn 'Affan r.a. telah dibawa kepadanya seorang perempuan yang melahirkan anak selepas baru mengandung enam bulan. Beliau memerintahkan supaya perempuan itu direjam.

Kemudian 'Alì r.a. berkata kepadanya, perempuan itu tidak boleh direjam kerana Allah SWT berfirman "Tempoh mengandung dan menyusu selama tiga puluh bulan" dan firman Allah SWT lagi: "Ibu-ibu akan menyusui anak-anak mereka dua tahun penuh bagi mereka yang mahu menggenapkan (tempoh) penyusuan. Maka, kata Ali r.a. tempoh maksimum mengandung ialah enam bulan.Lalu perempuan itu tidak boleh dihukum rejam. Uthman lalu mengarahkan supaya perempuan itu dibawa kembali. Bagaimanapun, dia telah direjam sebelum itu." ${ }^{37}$

Bagaimanapun, perbezaan pendapat ini mungkin boleh diselesaikan dengan baik berasaskan kemajuan sains dan teknologi sekarang ini, termasuk dalam sains penyiasatan sendiri. Apa yang penting ialah untuk menentukan tanpa keraguan yang munasabah samada kehamilan berkenaan berlaku akibat perzinaan atau sebaliknya.

Dalam jenayah mencuri berlaku perbincangan di kalangan para fuqaha apabila terdapat barang curi dalam simpanan (hiyāzah) tertuduh yang mendakwa bahawa barang itu miliknya sendiri. Mengikut pendapat sesetengah para fuqaha, dakwaan bahawa barang itu adalah miliknya sendiri merupakan suatu keraguan yang boleh menggugurkan hudud daripadanya. ${ }^{38}$ Bagaimanapun, persoalannya kalau begitulah hukumannya tidaklah ia akan membuka ruang yang luas kepada para pencuri untuk melepaskan diri daripada hukuman hudud dengan berdusta mengatakan bahawa barang berkenaan miliknya?

Dalam bukunya al-Ṭuruq al-Ḥkmiyyah, Ibn al-Qayyim menjawab:

"Para imam dan khalifah al-Rasyidin sentiasa menjatuhkan hukuman potong tangan apabila barang curi berkenaan didapati berada dalam simpanan tertuduh. Bukti (al-qarinah) ini sebenarnya lebih kuat daripada saksi dan

\footnotetext{
37 Ibid., h. 298.

38 Al-Sarakhsi (1957), op.cit., j. 9. h. 189.
} 
pengakuan. Kerana keterangan saksi dan pengakuan itu merupakan penyataan yang mungkin betul dan mungkin tidak. Sedangkan keberadaan harta berkenaan bersama tertuduh merupakan kenyataan yang jelas dan tidak boleh diragui lagi." ${ }^{39}$

Dalam jenayah minum arak pula perbincangan timbul dalam kes apabila terdapat bau arak dimulut tertuduh atau dia muntahkan arak. Mengikut pendapat sesetengah para fuqaha hukuman hudud tidak boleh dikenakan ke atas orang berkenaan kerana ada keraguan samada bau tersebut benar-benar bau arak. Malah terdapat juga keraguan samada dia meminum arak itu atas pilihannya sendiri atau kerana keliru atau terpaksa. Ini adalah pandangan jumhur fuqaha, termasuk mazhab Abū Hanifah, al-Syāfi '⿳亠口冋 dan al-Thauri. ${ }^{40}$ Sementara golongan kedua pula berpendapat bahawa qarinah seperti itu boleh diterima sebagai asas hukuman hudud ke atas tertuduh. Antara mereka yang berpendapat seperti ini ialah mazhab Mālikì dan sestengah para fuqaha mazhab Hanbali. ${ }^{41}$

Mengikut Ibn al-Qayyim, ini adalah amalan yang diwarisi sejak daripada khulafa al-Rasyidin lagi. ${ }^{42}$

Agak jelas sekali perbezaan-perbezaan pendapat ini berlaku kerana tidak ada dalil-dalil khusus daripada al-Quran atau alSunnah mengenai persoalan seperti itu. Segala pandangan banyak berdasarkan kepada ijtihad yang berasaskan dalil-dalil umum alQuran dan al-Sunnah dan penganalisaannya terhadap realiti hidup dan kehakiman pada waktu itu. Maka pada masa ini tradisi ijtihad ini perlu dilanjutkan supaya keadilan dapat ditegakkan dengan sebaik-baiknya.

\section{Kenyataan Pakar (al-khibrah)}

Dalam beberapa keadaan hakim memerlukan pandangan pakar bagi memberi nasihat dalam hal-hal tertentu untuk menghilangkan keraguan. Kebenaran untuk mendengar nasihat pakar ini terkandung dalam pengertian umum ayat.

\footnotetext{
39 Ibn al-Qayyim (1318H), op.cit., h. 6.

40 Ibn al-Humām (1315H), op.cit., j. 4, h. 184.

41 Ibn Qudāmah (t.t), op.cit., j. 10, h. 332.

42 Ibn al-Qayyim (1318H), op.cit., h. 80.
} 


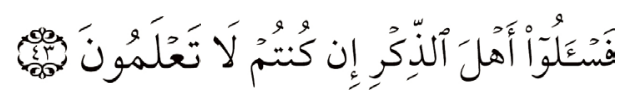

Maksudnya:

"Maka bertanyalah kepada orang yang mempunyai pengetahuan jika kamu tidak mengetahui”

Surah al-Naḥl (16): 43

Dalam al-Mabsūt al-Sarakhsì menyebut:

"Apabila pemerintah merasa ragu tentang harga barang yang dicuri itu dan para pakar juga berbeza pendapat tentangnya, di mana sebahagian daripada mereka menyebut ianya bernilai sepuluh dirham, sementara sebahagian yang lain mengatakan kurang dari itu, pencuri itu tidak boleh dihukum potong tangan. Kerana syarat cukup nisab perlu diambil kira secara hakiki, di mana ia dikira tidak tercapai kalau sekiranya para penilai berbeza pendapat tentangnya." ${ }^{43}$

Kata Ibn al-Humam:

"Dalam Muwatta'nya, Mālik meriwayatkan daripada 'Abdullah Ibn Abi Bakr daripada bapanya daripada 'Imrah binti 'Abd al-Rahman bahawa seseorang telah mencuri buah utrujjah pada zaman 'Uthman Ibn 'Affan. 'Uthman meminta supaya buah itu dinilai, lalu ia dinilai sebanyak kurang tiga dirham dua belas dinar. Beliau lalu memotong tangan orang itu." 44

Kata Ibn Qudāmah:

"Apabila ada perbezaan pendapat samada luka (yang dialami) itu parah atau tidak atau ada perbezaan pendapat tentang penyakit yang dihidapi seseorang, sekurangkurangnya dua orang doktor perlu memberi pandangan masing-masing. Bagaimanapun, kalau hanya ada seorang doktor sahaja, seorang pun cukup." ${ }^{25}$

\footnotetext{
43 Al-Sarakhsi (1957), op.cit., j. 9. h. 221.

44 Ibn al-Humām (1315H), op.cit., j. 4, h. 221.

45 Ibn Qudāmah (t.t.), op.cit., j. 12, h. 161.
} 
Kata Ibn al-Qayyim:

"Para guru saya menjelaskan dalam keadaan yang memerlukan, kesaksian seorang lelaki tanpa sumpah pun boleh diterima. Pandangan ini dinukilkan oleh al-Kharqi dalam Mukhtasarnya. Kata beliau: Keterangan seorang doktor yang adil boleh diterima dalam menentukan kadar luka sekiranya pandangan seorang doktor lagi tidak dapat diperolehi." ${ }^{46}$

Semua kenyataan di atas menunjukkan bahawa para fuqaha berpendapat pendapat pakar boleh diterima sebagai satu keterangan di mahkamah yang boleh menjadi asas kepada keputusan menjatuhkan hukuman hudud ke atas pesalah.

\section{Pengetahuan Hakim (Ma'lūmat al-Qāội)}

Apa yang dimaksudkan di sini bukanlah maklumat yang diperolehi oleh hakim bicara melalui proses perbicaraan kes berkenaan. Apa yang dimaksudkan ialah maklumat yang diperolehi oleh hakim berkenaan di luar mahkamah sebagai seorang biasa. Contohnya hakim berkenaan melihat sendiri kejadian itu atau telah mendengar tentangnya dairpada orang ramai.

Para fuqaha berbeza pendapat tentang pekara ini, samada boleh diterima sebagai asas penentuan hukum atau sebaliknya.

Mengikut pendapat dalam mazhab al-Syāfi $\bar{i}$, apa sahaja pengetahuan yang diperolehi oleh hakim berkenaan secara biasa tidak boleh digunakan sebagai asas penentuan hukum. Tetapi kalau sekiranya maklumat itu diperolehi melalui dua orang saksi yang dikenalinya sebagai bersifat adil dia boleh menggunakan maklumat dari luar mahkamah itu sebagai asas kepada hukuman.

Dalam mazhab Hanafí, maklumat seperti itu tidak boleh digunakan dalam kes-kes hudud walaupun boleh dalam kes-kes yang berkait dengan hak individu. Sebabnya kerana jenayah hudud menyentuh hak Allah (masyarakat umum), sedangkan hakim mewakili kepentingan mereka.

46 Ibn al-Qayyim (1318H), op.cit., h. 84. 
Lain pula pendapat mazhab Zahirī. Bagi mazhab ini hakim perlu menggunakan maklumat peribadinya itu dalam semua kes termasuk kes-kes hudud. Kata Ibn Hazm, asas yang paling kukuh ialah pengetahuannya sendiri, kemudian pengakuan, dan kemudian baru keterangan saksi. ${ }^{47}$

\section{Dokumen (al-Kitābah)}

Yang dimaksudkan ialah dokumen yang boleh menjadi dalil kepada berlakunya jenayah berkenaan. Antara contohnya ialah tulisan yang mengandungi pengakuan tertuduh melakukan jenayah berkenaan.

Walaupun ada pandangan yang menerima dokumen sebagai salah satu bentuk keterangan yang boleh mensabitkan kesalahan dalam kes-kes sivil namun dalam kes-kes jenayah mereka berpendapat hanya tulisan dalam bentuk pengakuan sahaja yang boleh diterima. Itupun hanyalah sebagai satu pengakuan (al-Iqrar) sahaja. Kata Aḥmad Fathi Bahnasi, kalau sekiranya tulisan itu mengandungi pengakuan melakukan jenayah hudud dan yang tertuduh mengaku itu adalah tulisannya maka dengan itu dia dianggap telah melakukan dua pengakuan. Tetapi kalau yang tertuduh menafikan bahawa itu adalah pengakuannya maka dia dianggap sebagai telah menafikan atau menarik balik pengakuannya yang terdahulu. ${ }^{48}$

\section{Sumpah (al-Yamin)}

Mengikut para fuqaha, ada tiga jenis sumpah yang mungkin berlaku di mahkamah. Pertamanya, sumpah pendakwa, keduanya sumpah yang terdakwa, dan yang ketiganya sumpah saksi.

Sumpah pihak pendakwa boleh berlaku dalam dua bentuk. Pertamanya dalam bentuk "qasāmah". Ia bermaksud sumpah bagi tujuan untuk mensabitkan kesalahan ke atas yang terdakwa berasaskan bukti awal (al-Lawth) yang ada.

Secara popularnya sumpah qasamah ini berlaku dalam kes pembunuhan. Ulama berbeza pendapat samada ia merupakan cara untuk mensabitkan kes atau menolak sabitan kes itu.

47 Ibn al-Qayyim (1318H), op.cit., h. 175.

48 Aḥmad Fatḥi Bahnasi (1962), op.cit., hh. 187-188. 
Dalam jenayah hudud ia hanya boleh berbangkit dalam kes mencuri. Itupun dengan syarat ada bukti awal (al-lawth), iaitu keberadaan barang yang dicuri bersama tertuduh.

Secara lebih jelasnya, adalah menjadi kaedah umum dalam Syariat Islam pihak pendakwa perlu membawa saksi untuk membuktikan dakwaannya. Kalau tidak, dakwaan itu tidak boleh disabitkan. Walau bagaimanapun, dalam kes mencuri ini pendakwa akan diberi peluang untuk bersumpah dengan syarat ada bukti bahawa barang yang dicuri itu ada bersama yang tertuduh (al-lawth).

Walau bagaimanapun, ia tidak boleh mensabitkan hukuman hudud itu sendiri, iaitu potong tangan. Sebaliknya ia sekadar boleh mensabitkan hukuman yang berkait dengan masalah kehartaan sahaja, iaitu memulangkan balik harta yang dicuri itu kalau masih ada atau membayar ganti rugi kalau sudah musnah. ${ }^{49}$

Bentuk kedua ialah sumpah yang ditolak (al-yamin almardūdah). Sumpah seperti ini boleh berlaku dalam kes mencuri juga dan dalam kes qadhf. Secara prinsipnya kalau A mendakwa B dengan satu kesalahan tetapi tidak ada saksi untuk mensabitkan kesalahan itu, dan B pula tidak mengaku salah, tidak ada kesalahan yang boleh disabitkan. Tetapi dalam kes tuduhan mencuri, hakim, atas permintaan pendakwa boleh meminta yang kena tuduh bersumpah untuk membersihkan dirinya daripada tuduhan tersebut. Kalau dia bersumpah dia akan terlepas daripada tuduhan itu. Tetapi kalau dia enggan bersumpah dia akan dianggap "nukūl" iaitu enggan menggunakan peluang bersumpah untuk membersihkan dirinya. Dengan itu juga bererti sumpah itu dipulangkan kembali kepada pendakwa.

Walau bagaimanapun, sumpah seperti ini hanya boleh mensabitkan hukuman ganti rugi harta sahaja dan bukan hukuman hudud, iaitu potong tangan. ${ }^{50}$

Dalam kes qadhf, kalau pihak yang melakukan qadhf itu tidak mempunyai saksi untuk menyokong tuduhannya dia boleh meminta pihak yang kena qadhf bersumpah membersihkan

$49 \quad$ Ibid., h. 191.

50 Al-Kāsāni (t.t.), op.cit., j. 7, h. 81; Ibn Qudāmah (t.t.), op.cit., j. 10, h. 128 . 
dirinya. Kalau pihak yang kena qadhf itu enggan bersumpah qadhf itu dikira benar dan pihak yang melakukan qadhf akan dikira benar dan pihak yang melakukan qadhf akan terlepas daripada hukuman qadhf. Ini adalah pandangan mazhab Syafi 'i. Kata mereka, sumpah seperti ini hanya boleh berlaku dalam kes qadhf sahaja dan tidak dalam kes-kes hudud yang lain. Ini kerana qadhf itu sendiri adalah pencerobohan terhadap kepentingan individu, tidak seperti jenayah hudud yang lain di mana pihak dicerobohi di dalamnya ialah kepentingan awam. ${ }^{51}$

Sebaliknya para fuqaha mazhab lain tidak berpendapat begitu. Bagi mereka, sumpah seperti ini tidak boleh diterima pakai dalam apa sahaja kes hudud, termasuk kes qadhf. Namun ada juga di kalangan mereka yang mengatakan boleh tetapi tidak melibatkan hukuman hudud, cuma ta'zir sahaja. ${ }^{52}$

Sumpah pihak yang kena dakwa pula tidak boleh berlaku dalam kes hudud. Kerana tujuan hakim meminta yang terdakwa bersumpah hanyalah untuk bertindak balik sekiranya dia enggan atas dasar berlaku keengganan $(n u k \bar{u} l)$ yang boleh mengembalikan peluang bersumpah itu kepada pihak yang mendakwa. Tetapi oleh kerana dalam kes hudud sumpah yang dikembalikan (al-yamin al-mardüdah) itu tidak boleh diterima pakai maka sumpah yang terdakwa tidak berbangkit. ${ }^{53}$

Bagaimanapun, dalam kes mencuri sumpah seperti ini boleh diterima pakai bagi tujuan mensabitkan hukuman ganti rugi harta yang dicuri sahaja dan bukan hukuman hudud potong tangan, iaitu sama dengan sumpah qasāmah yang dihuraikan di atas. ${ }^{54}$

\footnotetext{
51 Al-Anșārī (1326H), Asnā al-Mațāib, j. 4. Kaherah: Al-Halabī, h. 402.

52 Al-Kāsāni (t.t.), op.cit. j. 7, h. 52; Ibn Qudāmah (t.t.), op.cit., j. 10, h. 126.

53 Al-Sarakhsi (1957), op.cit., j. 16, h. 116; Ibn al-Hummam (1315H), op.cit., j. 4, h. 209.

54 Ibn Qudāmāh (t.t.), op.cit., j. 10, h. 310.
} 


\section{PENUTUP}

Samada Mahkamah terikat atau sebaliknya dengan kaedah tertentu dalam menerima dan menolak pembuktian dalam kes-kes hudud suatu persoalan yang masih boleh diperbincangkan. Kerana ia merupakan masalah khilafiah yang telah diperdebatkan oleh para ulama sejak zaman klasik lagi.

Namun apa yang penting dalam konteks tulisan ini ialah Islam mempunyai kaedah yang ketat dalam menerima apa-apa keterangan yang boleh nensabitkan mana-mana kes Hudud. Pertamanya kerana Islam mahu mempastikan keadilan berlaku di Mahkamah dalam kadar yang maksimum. Selain daripada itu ialah kerana Hudud merupakan jenayah berat yang perlu ditangani dengan penuh hati-hati agar ia dapat diurus dengan berkesan.

Bagi tujuan yang sama Islam meletakkan syarat-syarat yang ketat dalam menerima apa saja keterangan baik berupa saksi, pengakuan atau bukti keadaan (qarinah) meskipun dalam konsep biasa kaedah-kaedah seperti ini merupakan kaedah-kaedah yang kukuh. Namun selain daripada itu Islam juga membuka ruang bagi perkembangan kaedah pembuktian ini dengan menerima pengetahuan Hakim sendiri, dokumen, pendapat pakar dan sumpah sebagai bahan bukti yang layak diterima. Bagaimana pun para fuqaha berbeza pendapat dalam perkara ini. Bagi kita sekarang perbezaan pendapat ini boleh dijadikan sebagai asas bagi memperbaharui pandangan fiqh selaras dengan kemajuan dan kepentingan semasa. Pokoknya ialah keadilan perlu ditegakkan dan dalam menegakkan keadilan tidak sepatutnya mana-mana pihak teraniaya.

Begitulah hudud, suatu kaedah hukumman yang dikatakan berat. Namun apabila dilihat aspek pembuktiannya ternampak bahawa apa yang dilihat sebagai berat itu tidak sangat menggerunkan kerana ia dikawal oleh kaedah pembuktian yang ketat bagi menjamin keadilan tidak tercemar. 